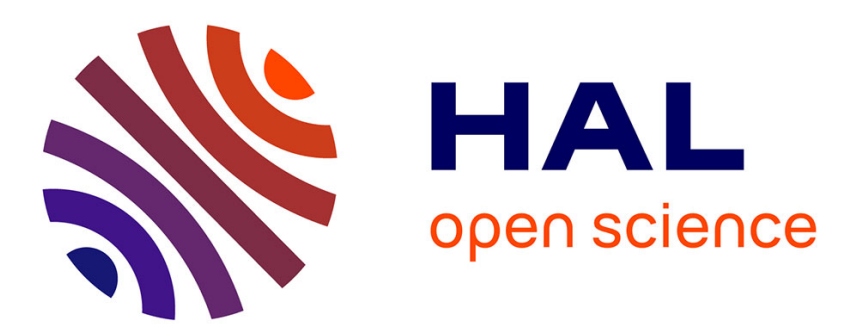

\title{
Inhibition of carcinogen-bioactivating cytochrome P450 1 isoforms by amiloride derivatives.
}

\author{
Lydie Sparfel, Laurence Huc, Marc Le Vée, Mireille Desille, Dominique \\ Lagadic-Gossmann, Olivier Fardel
}

\section{- To cite this version:}

Lydie Sparfel, Laurence Huc, Marc Le Vée, Mireille Desille, Dominique Lagadic-Gossmann, et al.. Inhibition of carcinogen-bioactivating cytochrome P450 1 isoforms by amiloride derivatives.. Biochemical Pharmacology, 2004, 67 (9), pp.1711-1719. 10.1016/j.bcp.2004.01.005 . hal-02681620

\section{HAL Id: hal-02681620 \\ https://hal.inrae.fr/hal-02681620}

Submitted on 31 May 2020

HAL is a multi-disciplinary open access archive for the deposit and dissemination of scientific research documents, whether they are published or not. The documents may come from teaching and research institutions in France or abroad, or from public or private research centers.
L'archive ouverte pluridisciplinaire HAL, est destinée au dépôt et à la diffusion de documents scientifiques de niveau recherche, publiés ou non, émanant des établissements d'enseignement et de recherche français ou étrangers, des laboratoires publics ou privés. 


\title{
Inhibition of carcinogen-bioactivating cytochrome P450 1 isoforms by amiloride derivatives
}

\author{
Lydie Sparfel*, Laurence Huc, Marc Le Vee, Mireille Desille, \\ Dominique Lagadic-Gossmann, Olivier Fardel
}

\author{
INSERM U456, Détoxication et Réparation Tissulaire, Faculté des Sciences Pharmaceutiques et Biologiques, \\ Université de Rennes I, 2 avenue du Prof Léon Bernard, 35043 Rennes cédex, France
}

Received 22 October 2003; accepted 7 January 2004

\begin{abstract}
We examined the effects of amiloride derivatives, especially 5-( $N$-ethyl- $N$-isopropyl)amiloride (EIPA), on the activity of cytochrome P450 (CYP) 1 isoforms, known to metabolize carcinogenic polycyclic aromatic hydrocarbons (PAHs), such as benzo(a)pyrene (BP), into mutagenic metabolites and whose cellular expression can be induced through interaction of PAHs with the arylhydrocarbon receptor. EIPA was found to cause a potent and dose-dependent inhibition of CYP1-related ethoxyresorufine $O$-deethylase (EROD) activity in both liver cells and microsomes. It also markedly reduced activity of human recombinant CYP1A1 enzyme through a competitive mechanism; activities of other human CYP1 isoforms, i.e. CYP1A2 and CYP1B1, were also decreased. However, EIPA did not affect BP-mediated induction of CYP1A1 mRNA and protein levels in rat liver cells, likely indicating that EIPA does not block activation of the arylhydrocarbon receptor by PAHs. Inhibition of CYP1 activity by EIPA was associated with a decreased metabolism of BP, a reduced formation of BPderived DNA adducts and a diminished BP-induced apoptosis in liver cells. The present data suggest that amiloride derivatives, such as EIPA, may be useful for preventing toxicity of chemical carcinogens, such as PAHs, through inhibition of CYP1 enzyme activity.
\end{abstract}

(C) 2004 Elsevier Inc. All rights reserved.

Keywords: Amiloride derivatives; Cytochromes P450 1 isoforms; Liver microsomes; Benzo(a)pyrene; Chemoprevention; Carcinogen

\section{Introduction}

Most chemicals must be activated to exert their carcinogenic effects. This is the case for benzo(a)pyrene (BP), an important environmental polycyclic aromatic hydrocarbon (PAH) considered as a procarcinogen for various organs, including lung and skin [1]. Indeed, metabolism of BP via drug-metabolizing enzymes, such as cytochromes P450 (CYPs), especially those of CYP1 family (CYP1A1, CYP1A2 and CYP1B1), can produce genotoxic electrophile intermediates that can covalently bind DNA to form mutagenic DNA adducts and hence might be involved in the initial events of carcinogenesis [2]. Interestingly, BP usually

Abbreviations: BP, benzo(a)pyrene; CYP, cytochrome P450; EIPA, 5( $N$-ethyl- $N$-isopropyl)amiloride; EROD, ethoxyresorufine $O$-deethylase; MIA, 5-( $N$-methyl- $N$-isobutyl)amiloride; PAH, polycyclic aromatic hydrocarbon; PBS, phosphate-buffered saline; TCDD, 2,3,5,7-tetrachlorodibenzo-p-dioxin

${ }^{*}$ Corresponding author. Tel.: +33-2-23-23-48-68; fax: +33-2-23-23-47-94.

E-mail address: lydie.sparfel@rennes.inserm.fr (L. Sparfel). strongly up-regulates CYP1 expression by interacting with the aryl hydrocarbon receptor, therefore, increasing its own metabolic activation in various cell types [3].

Various natural and synthetic compounds are capable of reducing CYP1-mediated bioactivation of PAHs and thus may protect against carcinogenic potential of these chemicals. They usually act through inhibition of PAH-mediated CYP1 up-regulation and/or direct inhibition of CYP1 activity [4,5]. They belong to different chemical classes and, for example, coumarins, such as imperatorin or isopimpinellin [6], anthraquinones, such as purpurin or alizarin [7], some flavonoids [8] and the dithiolethione oltipraz [9] have been reported to decrease activity of CYP1 enzymes.

The diuretic drug amiloride and its chemical analogues, such as 5 -( $N$-ethyl- $N$-isopropyl)amiloride (EIPA), are well-known inhibitors of the $\mathrm{Na}^{+} / \mathrm{H}^{+}$exchanger, a plasma membrane protein involved in intracellular $\mathrm{pH}$ regulation, cell metabolism and cell proliferation [10]. In this context, amiloride has been reported to inhibit tumor growth both in vivo and in vitro [11,12]. More recently, this compound has also been demonstrated to afford some protection against 
carcinogenesis induced by $N$-methyl- $N^{\prime}$-nitro- $N$-nitrosoguanidine in rodents [13]. This indicates that the use of amiloride may contribute to chemoprevention although the molecular and cellular bases for this effect remain mainly to be determined. As amiloride and its analogues display some structural similarities with the chemopreventive agent oltipraz, i.e. the presence of a pyrazinyl group (Fig. 1), they may share some of the oltipraz properties putatively contributing to its chemopreventive action, especially its inhibitory effects towards CYP1 activity [9]. To test such an hypothesis, we have presently studied the effects of amiloride derivatives, especially EIPA, on CYP1 activity. EIPA was found to reduce the activity of different CYP1 isoforms, namely, CYP1A1, CYP1A2 and CYP1B1, thereby preventing BP bioactivation and toxicity in cultured liver cells.

\section{Materials and methods}

\subsection{Chemicals}

BP, amiloride, EIPA, 5-( $N$-methyl- $N$-isobutyl)amiloride (MIA), Hoechst 33342 and ethoxyresorufin were supplied from Sigma Chemicals Co; the chemical structures of amiloride and EIPA are depicted on Fig. 1. 2,3,5,7-Tetrachlorodibenzo- $p$-dioxin (TCDD) was provided by Cambridge Isotopes Laboratories, whereas $\left[{ }^{3} \mathrm{H}\right] \mathrm{BP}$ (specific activity $50 \mathrm{Ci} / \mathrm{mmol}$ ) was obtained from Isobio. Cariporide was kindly provided by Aventis. Microsomes from human B lymphoblastoid cells co-expressing NADPH-CYP reductase and human recombinant CYP1A1, CYP1A2, CYP1B1, CYP2A6, CYP2B6, CYP2E1 or CYP3A4 were purchased from Gentest. All other compounds were commercial products of the highest purity available.

\subsection{Cell isolation and culture}

Hepatocytes from adult male Sprague-Dawley rats weighing $150-200 \mathrm{~g}$ were isolated by perfusion of the liver and then cultured as previously described [14]. Human hepatoma Hep3B cells were cultured in Williams' E medium containing $10 \%$ fetal calf serum, $0.2 \mathrm{mg} / \mathrm{ml}$ bovine serum albumin, $10 \mu \mathrm{g} / \mathrm{ml}$ bovine insulin, $2 \mathrm{mM} \mathrm{L-}$ glutamine, $100 \mathrm{U} / \mathrm{ml}$ penicillin, $10 \mu \mathrm{g} / \mathrm{ml}$ streptomycin and $0.25 \mu \mathrm{g} / \mathrm{ml}$ hydrocortisone hemisuccinate. The F258 rat liver epithelial cell line was cultured in the same Williams' E medium as previously described [15].

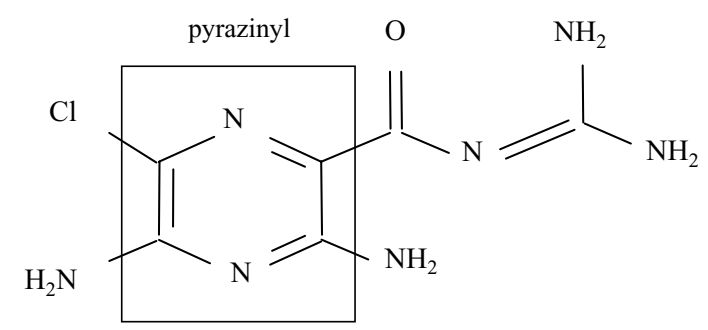

amiloride

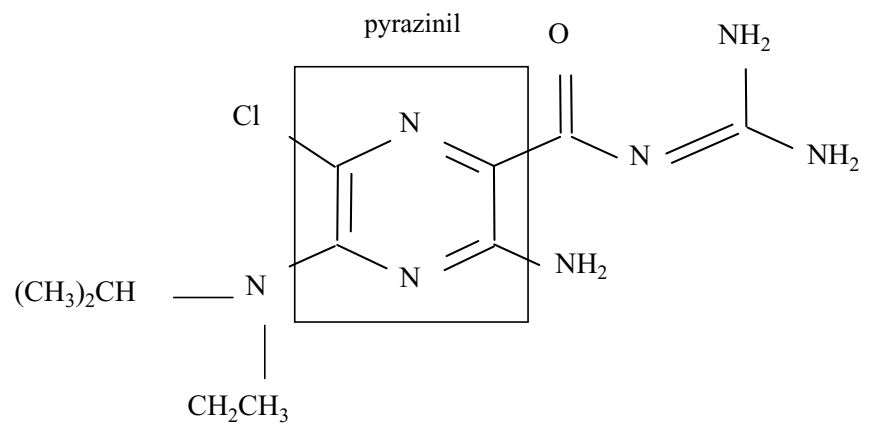

EIPA

pyrazinil

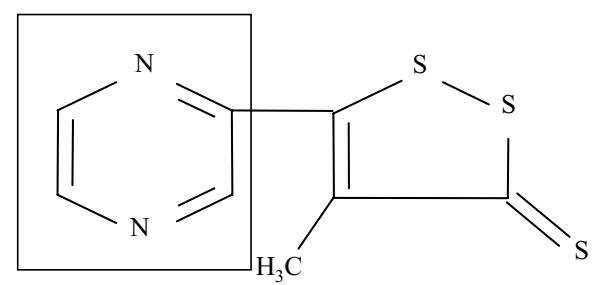

oltipraz

Fig. 1. Chemical structures of amiloride, EIPA and oltipraz. 
Chemicals were used as stock solutions in dimethylsulfoxide; the final concentration of this solvent in culture medium was always less than $0.2 \%$ (v/v) and control cultures received the same dose of vehicle as treated cultures.

\subsection{Isolation of total RNAs and Northern blot analysis}

Total RNAs were extracted from cultured hepatocytes by the guanidinium thiocyanate/cesium chloride method of Chirgwin et al. [16], as modified by Raymondjean et al. [17]. For Northern blotting, $10 \mu \mathrm{g}$ of total RNAs were subjected to electrophoresis in a denaturing formaldehyde/agarose gel and transferred onto Hybond $\mathrm{N}+$ sheets (Amersham). The sheets were prehybridized and then hybridized with a ${ }^{32} \mathrm{P}$-labeled CYP1A1 probe [18], washed, dried and autoradiographed at $-80^{\circ} \mathrm{C}$. Equal RNA loading onto the gel and efficiency of the transfer were checked by rehybridizing the blot with an $18 \mathrm{~S}$ rRNA probe.

\subsection{Preparation of microsomal fractions}

Microsomal fractions were prepared from PAH-treated rat liver cells by differential centrifugation in $50 \mathrm{mM}$ Tris$\mathrm{HCl}$ buffer, $\mathrm{pH} 7.4$, containing $0.25 \mathrm{M}$ sucrose and $1 \mathrm{mM}$ EDTA as previously described [19]; they were stored at $-80{ }^{\circ} \mathrm{C}$ in $0.1 \mathrm{M}$ phosphate-buffered saline (PBS), $\mathrm{pH} 7.4$, containing $10 \%$ glycerol. Protein contents were determined using the Bradford method [20].

\subsection{Western blotting immunoassays}

Microsomal proteins were separated on a $10 \%$ polyacrylamide gel and electrophoretically transferred onto nitrocellulose sheets (Amersham). Sheets were blocked for $1 \mathrm{~h}$ with PBS containing 5\% skimmed milk and were then incubated with a goat anti-human CYP1A1 antibody (Daiichi Pure Chemicals Co). A peroxidase-conjugated antibody was next used as secondary antibody and blots were developed by chemoluminescence using the Amersham ECL detection system (Amersham).

\subsection{CYP activities in cultured cells and microsomes}

Ethoxyresorufine $O$-deethylase (EROD) activity was used as a measurement of CYP1A1, CYP1A2 and CYP1B1 activities [21] in PAH-treated liver cells and microsomal fractions as previously described [22]. Resorufin formation was monitored using a SpectraMax Gemini spectrofluorimeter (Molecular Devices); excitation and emission wavelengths were 544 and $590 \mathrm{~nm}$, respectively. Reaction rates were determined under linear conditions with various incubation times and protein concentrations.

CYP2A6-related coumarin 7-hydroxylase and CYP2B6related 7-benzoxyresorufin $O$-deethylase activities were quantified in human recombinant CYP isoforms using a fluorimetric assay [23]; excitation and emission wavelengths were 355 and $460 \mathrm{~nm}$ for CYP2A6 activity and 544 and $590 \mathrm{~nm}$ for CYP2B6 activity. CYP2E1-related chlorzoxazone 6-hydroxylase and CYP3A4-related testosterone $6 \beta$-hydroxylase activities were determined using the corresponding recombinant CYP enzymes by HPLC (Hewlett Packard Series 1100 and Waters system) as previously described [23].

To characterize the potential inhibitory effects of EIPA towards CYP1A1-mediated EROD activity, EROD assay was conducted at EROD concentrations ranging from 1.5 to $15 \mu \mathrm{M}$, in the presence of various EIPA concentrations $(0-20 \mu \mathrm{M})$, using recombinant CYP1A1-containing microsomes. Kinetic enzymatic parameters were estimated using a computer program designed for non-linear regression analysis (GraphPad Software, Prism 3.02), according to the Michaelis-Menten equation. The apparent Michaelis-Menten constant $\left(K_{\mathrm{m}}\right)$ and the maximal velocity $\left(V_{\max }\right)$ were obtained by non-linear regression analysis of enzymatic velocity versus different EIPA concentrations. Inhibition constant $\left(K_{\mathrm{i}}\right)$ was determined from secondary plot of $K_{\mathrm{m}} / V_{\max }$ versus 1/[EIPA]. To determine the mode of inhibition, Lineweaver-Burk linear regression was used for graphic plot of $1 / V$ versus $1 /[$ ethoxyresorufin].

\subsection{BP metabolism}

Confluent cultures of Hep3B cells, previously exposed to $10 \mathrm{nM}$ TCDD for $24 \mathrm{~h}$ in order to induce CYP1A1 expression [24], were treated by $0.1 \mu \mathrm{g} / \mathrm{ml}\left[{ }^{3} \mathrm{H}\right] \mathrm{BP}$ in the absence or presence of $20 \mu \mathrm{M}$ EIPA for $4 \mathrm{~h}$. Water-soluble BP metabolites were then extracted as described by Huberman et al. [25] and further quantified by scintillation counting.

\subsection{Measurement of BP-derived DNA adducts}

Confluent cultured F258 cells, previously exposed to $10 \mathrm{nM}$ TCCD for $24 \mathrm{~h}$ in order to induce CYP1A1 expression [24], were treated by $0.1 \mu \mathrm{g} / \mathrm{ml}\left[{ }^{3} \mathrm{H}\right] \mathrm{BP}$ in the absence or presence of 5 or $20 \mu \mathrm{M}$ EIPA for $1 \mathrm{~h}$. After two PBS washes, DNA was extracted as previously reported [4]. Amounts of $\left[{ }^{3} \mathrm{H}\right] \mathrm{BP}$ covalently bound to DNA were then determined by scintillation counting and normalized to amounts of DNA quantified by its absorbance at $260 \mathrm{~nm}$.

\subsection{Light microscopic detection of apoptosis}

Light microscopic detection of apoptosis was performed in both floating and adherent cells using Hoechst 33342 labeling. Briefly, F258 cells, growing in exponential phase, were treated by $5 \mu \mathrm{M}$ BP in the absence or presence of $20 \mu \mathrm{M}$ EIPA for $24 \mathrm{~h}$. Culture media and trypsinizedadherent cells were collected, washed with PBS, stained 
with Hoechst $33342(0.5 \mu \mathrm{g} / \mathrm{ml})$ and then examined using a fluorescence Olympus BX60 microscope. Cells with apoptotic nuclei, i.e. nuclei with condensed or fragmented chromatin, were then counted in comparison with total population ( $n>200$ nuclei).

\subsection{Statistical analysis}

Data were analyzed using the paired Student's $t$ test. For the variations of EROD activity measured in the absence or presence of EIPA, an analysis of variance followed by a multirange Dunnett's $t$ test was used. The level of significance was $P<0.05$.

\section{Results}

\subsection{Inhibition of CYP1-related EROD activity by the amiloride derivative EIPA}

To determine whether amiloride and its derivatives had an effect on catalytic activities of CYP1 enzymes, CYP1related EROD activity was quantified in primary rat hepatocyte cultures previously exposed to $5 \mu \mathrm{M} \mathrm{BP}$ for $24 \mathrm{~h}$ in the presence of increasing concentrations of amiloride $(0$ $100 \mu \mathrm{M})$, EIPA $(0-20 \mu \mathrm{M})$ and MIA $(0-20 \mu \mathrm{M})$. These concentrations were used since they are in the range of those found to inhibit $\mathrm{Na}^{+} / \mathrm{H}^{+}$exchanger [26]. Fig. 2 shows that amiloride decreased BP-induced EROD activity in primary rat hepatocytes in a dose-dependent manner; a marked inhibitory effect was seen only with $100 \mu \mathrm{M}$, a concentration found to alter cell viability using the 3-(4-5dimethylthiazol-2-yl)-2,5-diphenyltetrazolium bromide colorimetric viability assay (data not shown), whereas doses of 10 and $50 \mu \mathrm{M}$ were inactive. Synthetic amiloride analogues EIPA and MIA, none of them affecting cell viability at the concentrations used (data not shown), also decreased BP-induced EROD activity in rat hepatocytes in a concentration-dependent manner; the inhibitory effect began at a concentration as low as $1 \mu \mathrm{M}$ and was almost total at $20 \mu \mathrm{M}$ (Fig. 2). On the other hand, the benzoylguanidine derivative cariporide, a $\mathrm{Na}^{+} / \mathrm{H}^{+}$exchanger blocker that does not share structural similarities with amiloride and its derivatives, failed to alter EROD activity in primary rat hepatocytes when used at concentrations (30-60 $\mu \mathrm{M}$ ) affecting $\mathrm{Na}^{+} / \mathrm{H}^{+}$exchanger [26] (Fig. 2).

EIPA, which decreased EROD activity at low concentrations (1-20 $\mu \mathrm{M})$ in both primary rat hepatocytes (Fig. 2) and cultured human Hep3B liver cells (data not shown), was retained for the following experiments of this study. It was found to directly inhibit CYP1-related EROD activity in isolated microsomes from liver cells in a dose-dependent manner (Fig. 3).

To investigate whether EIPA affected the catalytic activity of different human isoforms of the CYP1 family, namely, CYP1A1, CYP1A2 and CYP1B1, the EROD assay was conducted with microsomes containing the different corresponding recombinant CYP1 enzymes in the presence of various concentrations of EIPA $(0-20 \mu \mathrm{M})$. As shown in Fig. 4, EIPA decreased CYP1A1, CYP1A2 and CYP1B1 catalytic activities in a concentration-dependent manner with a potent inhibitory effect on CYP1A1 $\left(\mathrm{IC}_{50}=\right.$ $0.5 \mu \mathrm{M})$ and to a lesser extent on CYP1A2 $\left(\mathrm{IC}_{50}=\right.$ $6 \mu \mathrm{M})$ and CYP1B1 $\left(\mathrm{IC}_{50}=7 \mu \mathrm{M}\right)$. By contrast, $20 \mu \mathrm{M}$ EIPA failed to obviously alter human CYP2A6, CYP2B6, CYP2E1 and CYP3A4 catalytic activities in recombinant human CYP-containing microsomes (Fig. 5).

To further characterize the inhibition of CYP1A1 catalytic activity by EIPA, enzyme kinetic experiments were performed with different substrate concentrations $(1.5-15 \mu \mathrm{M})$ in the presence of increasing EIPA concentrations $(0-20 \mu \mathrm{M})$. Lineweaver-Burk plot of enzyme kinetic data (Fig. 6A) was consistent with a competitive inhibitory effect of EIPA with a $K_{\mathrm{i}}$ of $2.85 \mu \mathrm{M}$ (Fig. 6B).

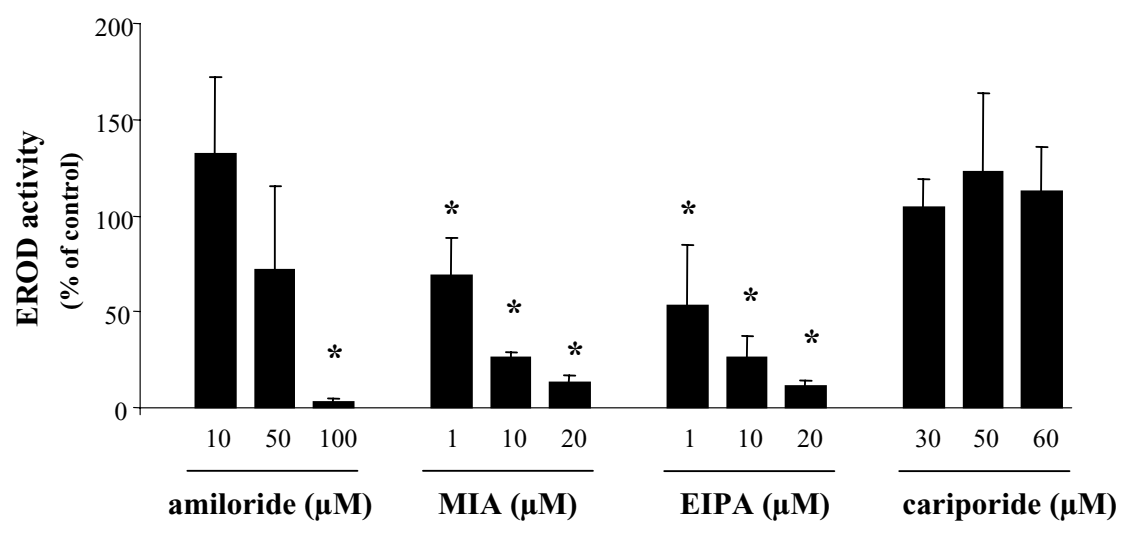

Fig. 2. Effects of amiloride, MIA, EIPA and cariporide on EROD activity in primary rat hepatocytes. Primary rat hepatocytes were treated with $5 \mu \mathrm{M}$ BP in the absence or presence of increasing concentrations of amiloride $(0-100 \mu \mathrm{M})$, MIA $(0-20 \mu \mathrm{M})$, EIPA $(0-20 \mu \mathrm{M})$ or cariporide $(0-60 \mu \mathrm{M})$ for $24 \mathrm{~h}$. EROD activity was then determined as described in Section 2. Data are expressed as the percentages of control EROD values measured in BP-treated cells not coexposed to amiloride derivatives ( $443 \pm 128 \mathrm{pmol}$ resorufin $/ \mathrm{min} / \mathrm{mg}$ proteins) and are the means $\pm \mathrm{S}$.D. of three independent experiments performed in triplicate. ${ }^{*} P<0.05$ when compared to amiloride derivatives-untreated cells. 


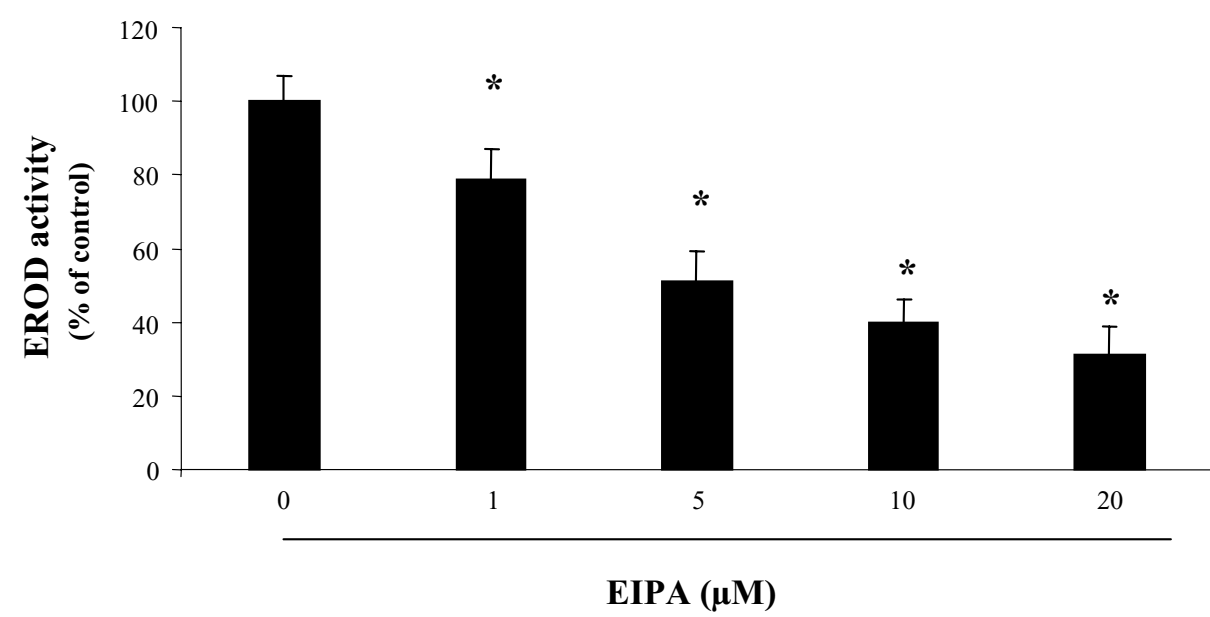

Fig. 3. Effects of EIPA on EROD activity in isolated microsomes. EROD activity in microsomes isolated from PAH-treated rat liver cells was determined in the presence of various concentrations of EIPA $(0-20 \mu \mathrm{M})$ as described in Section 2. Data are expressed as the percentages of control EROD values measured in the absence of EIPA $(3358 \pm 234 \mathrm{pmol}$ resorufin $/ \mathrm{min} / \mathrm{mg}$ protein) and are the means \pm S.D. of three independent experiments performed in triplicate. ${ }^{*} P<0.05$ when compared to EIPA-untreated cells.

\subsection{Lack of effects of EIPA on BP-mediated induction of CYP1A1 expression}

Since several blockers of CYP1 activity also alter CYP1 up-regulation by aryl hydrocarbon receptor agonists, such as PAHs $[4,5]$, we next examined the effects of EIPA on BP-mediated induction of CYP1A1 in primary rat hepatocytes. Northern blotting indicated that $20 \mu \mathrm{M}$ EIPA failed to alter up-regulation of CYP1A1 mRNA levels occurring in response to a 24-h exposure to BP (Fig. 7A). Likewise, it did not decrease CYP1A1 amounts in BP-treated primary hepatocytes as assessed by Western blotting (Fig. 7B).

\subsection{Inhibition of BP metabolism by EIPA}

The ability of EIPA to inhibit CYP1 enzymes known to bioactivate carcinogens, such as PAHs, led us to examine its effect on the formation of BP-derived metabolites in human Hep3B liver cells. Such cells, previously exposed to TCDD in order to up-regulate CYP1A1 expression, were found to produce water-soluble BP metabolites over a 4-h exposure time to $0.1 \mu \mathrm{g} / \mathrm{ml}\left[{ }^{3} \mathrm{H}\right] \mathrm{BP}$; this production was not observed in culture medium incubated in parallel with $\left[{ }^{3} \mathrm{H}\right] \mathrm{BP}$ in the absence of cells, indicating it to reflect specifically cell metabolism of BP and not spontaneous conversion of BP into water-soluble metabolites in culture

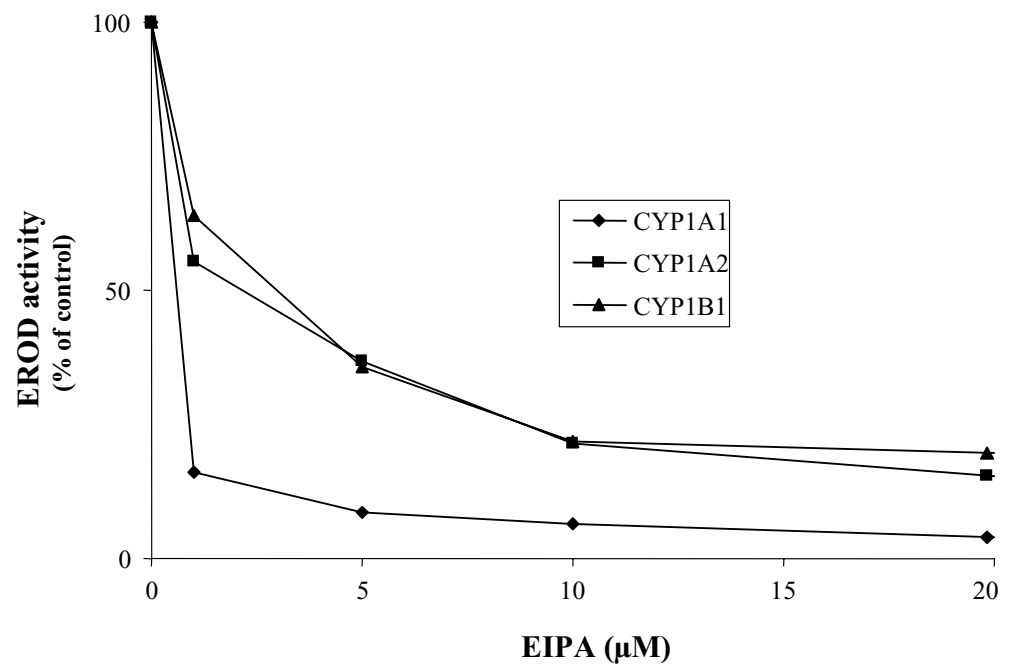

Fig. 4. Effects of EIPA on catalytic activities of human CYP1A1, CYP1A2 and CYP1B1. CYP1A1-, CYP1A2- and CYP1B1-related EROD activities were determined in the presence of various concentrations of EIPA $(0-20 \mu \mathrm{M})$ as described in Section 2. Data are expressed as the percentages of control EROD values measured in the absence of EIPA $(236 \pm 23 \mathrm{pmol}$ resorufin $/ \mathrm{min} / \mathrm{mg}$ protein for CYP1A1, $38 \pm 11 \mathrm{pmol} \mathrm{resorufin} / \mathrm{min} / \mathrm{mg}$ protein for CYP1A2 and $38 \pm 3 \mathrm{pmol}$ resorufin/min/mg protein for CYP1B1) and represent the mean of two independent experiments performed in duplicate. 


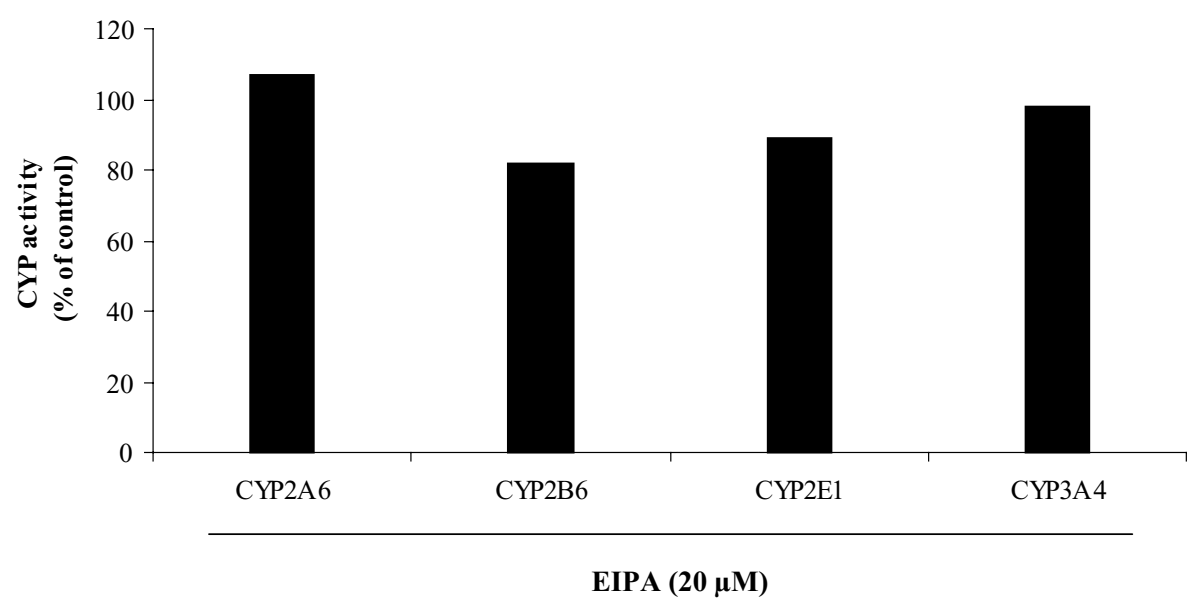

Fig. 5. Effects of EIPA on catalytic activities of human CYP2A6, CYP2B6, CYP2E1 and CYP3A4. CYP2A6-related coumarin 7-hydroxylation, CYP2B6related 7-benzoxyresorufin $O$-deethylation, CYP2E1-related chlorzoxazone 6-hydroxylation and CYP3A4-related testosterone 6 $\beta$-hydroxylation were determined in the absence or presence of $20 \mu \mathrm{M}$ EIPA. Data are expressed as the percentages of control CYP values measured in the absence of EIPA (242 $\pm 16 \mathrm{pmol}$ 7-hydroxycoumarin/min/mg protein for CYP2A6, $22 \pm 5 \mathrm{pmol}$ resorufin/min/mg protein for CYP2B6, $74 \pm 18$ pmol 6-hydroxychlorzoxazone/min/mg protein for CYP2E1, $22 \pm 0.2 \mathrm{pmol} 6 \beta$-hydroxytestosterone/min/mg protein for CYP3A4) and represent the mean of two independent experiments performed in duplicate.

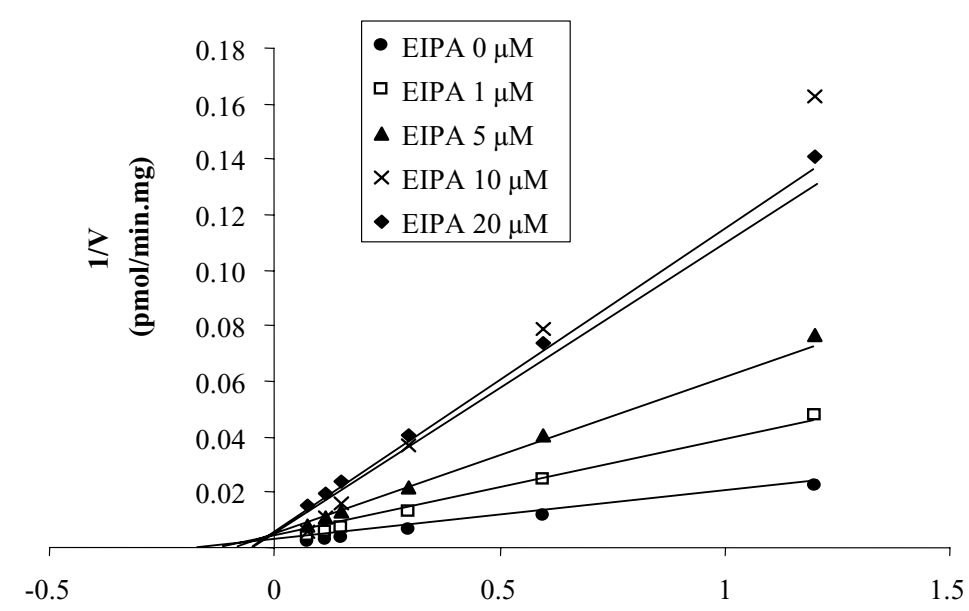

(A)

1/[ethoxyresorufin $\mu \mathrm{M}]$

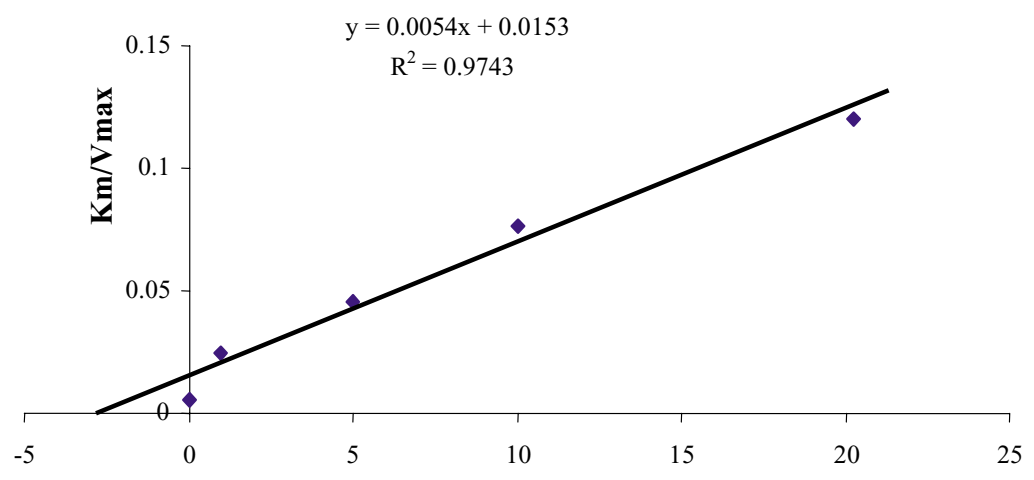

(B)

EIPA $(\mu \mathrm{M})$

Fig. 6. Inhibition kinetics of human CYP1A1-mediated EROD activity by EIPA. Recombinant CYP1A1-containing microsomes were incubated with increasing concentrations of ethoxyresorufin $(1.5-15 \mu \mathrm{M})$ in the presence of various EIPA concentrations $(0-20 \mu \mathrm{M})$ and EROD activity was determined as described in Section 2. (A) Representation of Lineweaver-Burk linear regression was generated from one representative out of two different experiments; correlation coefficients were 0.86 ( $0 \mu \mathrm{M}$ EIPA), 0.99 ( $1 \mu \mathrm{M}$ EIPA), 0.99 (5 $\mu \mathrm{M}$ EIPA), 0.99 (10 $\mu \mathrm{M}$ EIPA) and 0.99 (20 $\mu \mathrm{M}$ EIPA) (B) Plot of $K_{\mathrm{m}} / V_{\text {max }}$ vs. EIPA concentrations was obtained from Michaelis-Menten non-linear regression; $K_{\mathrm{i}}$ calculated as the negative value of $X$-axis intercept was $2.85 \mu \mathrm{M}$. Each point represents the mean of two independent experiments performed in duplicate. 
(A)

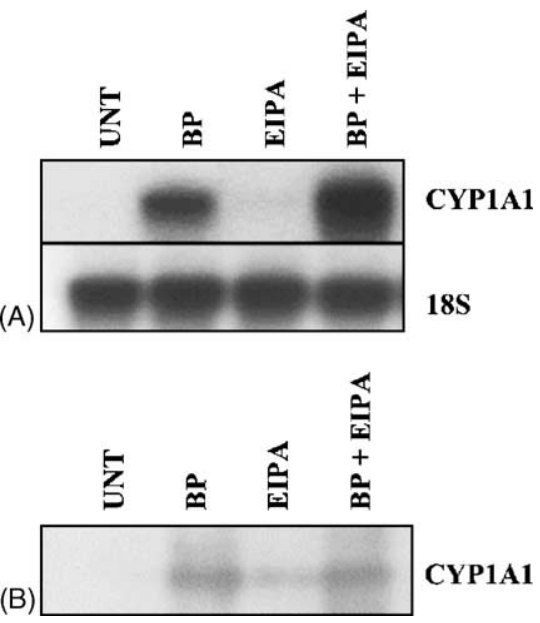

Fig. 7. Effects of EIPA on CYP1A mRNA (A) and protein (B) levels in primary rat hepatocytes. Cultured hepatocytes were either untreated (UNT), treated by $5 \mu \mathrm{M}$ BP or $20 \mu \mathrm{M}$ EIPA or co-exposed to BP and EIPA for $24 \mathrm{~h}$. Levels of mRNA (A) and protein (B) were then determined by Northern and Western blotting, respectively. Data are representative of three independent experiments.

medium (Fig. 8). Addition of $20 \mu \mathrm{M}$ EIPA significantly decreased the amounts of BP converted to water-soluble metabolites (Fig. 8).

\subsection{Inhibition of BP-derived DNA adduct formation and BP-induced apoptosis by EIPA}

We finally determined whether EIPA could prevent CYP1-related toxic effects of BP in liver cells. For this purpose, we used F258 rat liver cells previously shown to be targets for PAHs [15,27]. In such cells, EIPA used at $20 \mu \mathrm{M}$ significantly decreased the amounts of BP-derived DNA adducts formed over a 1-h exposure time to $0.1 \mu \mathrm{g} / \mathrm{ml}$
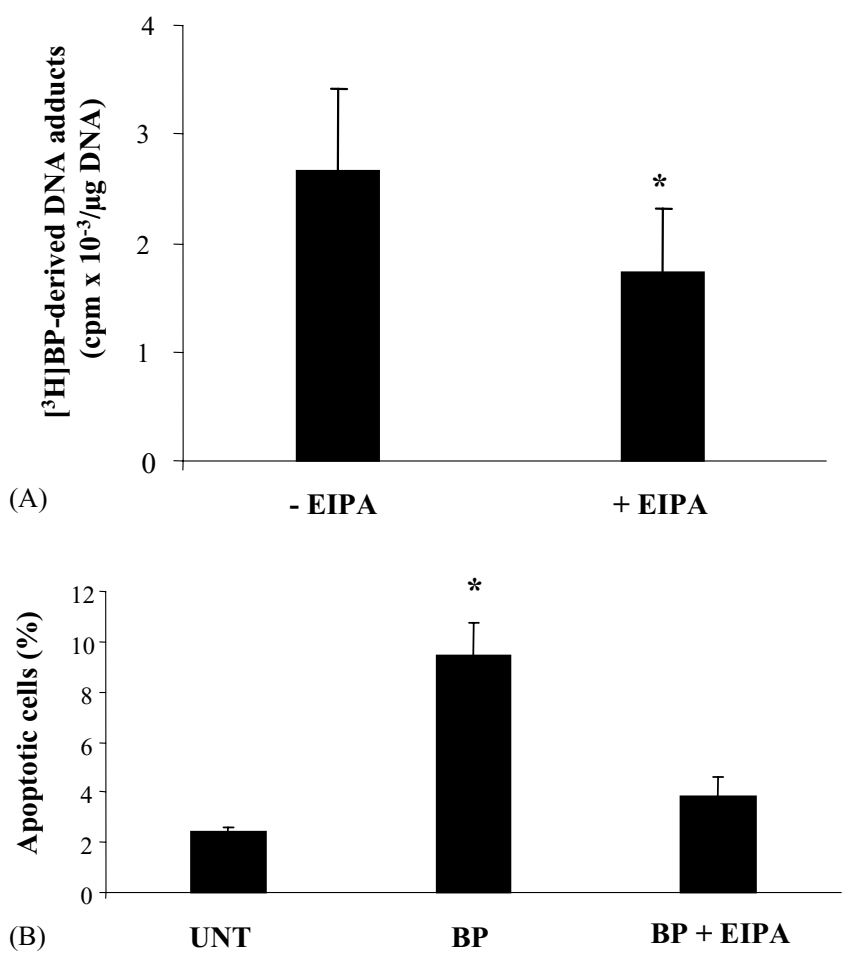

Fig. 9. Effects of EIPA on the formation of BP-derived DNA adducts (A) and BP-induced apoptosis (B) in liver epithelial F258 cells. (A) TCDDpretreated F258 cells were exposed to $0.1 \mu \mathrm{g} / \mathrm{ml}\left[{ }^{3} \mathrm{H}\right] \mathrm{BP}$ for $1 \mathrm{~h}$ in the absence or presence of EIPA. DNA was then purified and BP-derived DNA adducts were measured by scintillation counting and normalized to amounts of recovered DNA. The results are expressed as $\mathrm{cpm} / \mu \mathrm{g}$ DNA and are the means \pm S.D. of three independent experiments performed in duplicate. ${ }^{*} P<0.05$ when compared to EIPA-untreated cells. (B) F258 cells were either untreated (UNT) or treated by $5 \mu \mathrm{M} \mathrm{BP}$ in the absence or presence of $20 \mu \mathrm{M}$ EIPA for $24 \mathrm{~h}$. Apoptotic cells were then detected by fluorescence microscopy after Hoechst 33342 staining of nuclei as described in Section 2. Data are expressed as the percentages of apoptotic cells and are the means \pm S.D. of three independent experiments performed in duplicate. ${ }^{*} P<0.05$ when compared to BP-untreated cells.

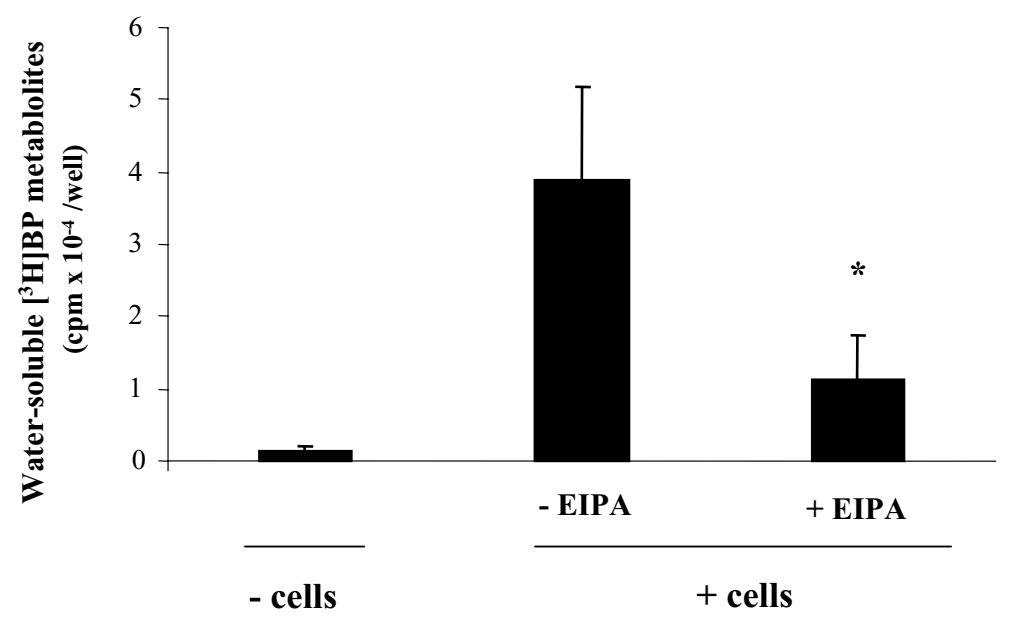

Fig. 8. Effect of EIPA on BP metabolism in liver cells. Liver Hep3B cells cultured in 24-well plates and pretreated by $10 \mathrm{nM}$ TCDD were exposed to $0.1 \mu \mathrm{g} /$ $\mathrm{ml}\left[{ }^{3} \mathrm{H}\right] \mathrm{BP}$ for $4 \mathrm{~h}$ in the absence or presence of $20 \mu \mathrm{M}$ EIPA. The amount of water-soluble $\left[{ }^{3} \mathrm{H}\right] \mathrm{BP}$ metabolites generated was then measured by scintillation counting as described in Section 2. As a control, water-soluble $\left[{ }^{3} \mathrm{H}\right] \mathrm{BP}$ metabolites were also evaluated in culture medium not incubated with cells. The results are expressed as $\mathrm{cpm} /$ well and are the means \pm S.D. of three independent experiments performed in duplicate. ${ }^{*} P<0.05$ when compared to EIPAuntreated cells. 
$\left[{ }^{3} \mathrm{H}\right] \mathrm{BP}$ (Fig. 9A). It also prevented the induction of apoptosis triggered by a $24-\mathrm{h}$ treatment by $5 \mu \mathrm{M} \mathrm{BP}$; indeed, the number of apoptotic cells, i.e. cells exhibiting Hoechst 33342-labeled nuclei, in BP-treated cultures, was greatly reduced in the presence of $20 \mu \mathrm{M}$ EIPA (Fig. 9B).

\section{Discussion}

In the present study, we report for the first time to the best of our knowledge that amiloride derivatives, such as EIPA, constitute potent inhibitors of drug-metabolizing CYP1 enzymes. Indeed, EIPA was found to inhibit CYP1-related EROD activity in both primary rat hepatocytes- and CYP1containing microsomes. Using human recombinant CYP1 isoforms, EIPA was furthermore demonstrated to block the activity of CYP1A1, CYP1A2 and CYP1B1, CYP1A1 being the most sensitive to the inhibitory effect of EIPA. EIPA, however, failed to alter activity of other CYPs, such as human CYP2A6, CYP2B6, CYP2E1 and CYP3A4 isoforms; in addition, it also failed to inhibit CYP2B-mediated pentoxyresorufin dealkylation in both primary rat hepatocytes and isolated microsomes from rat liver cells (data not shown). These data discard a general inhibitory action of amiloride derivative towards CYP. Analysis of kinetic parameters of CYP1A1-related EROD activity at various concentrations of substrates and EIPA revealed that EIPA behaves as a competitive inhibitor of human CYP1A1, with an estimated $K_{\mathrm{i}}$ of $2.85 \mu \mathrm{M}$. Similarly, other CYP1 inhibitors, such as oltipraz [9], primaquine [28] and resveratrol [5], act as competitive inhibitors with $K_{\mathrm{i}}$ in the $\mu \mathrm{M}$ range. By contrast, galangin blocks CYP1A1 activity in a noncompetitive manner [4], whereas the food pigment purpurin seems to be a mixed-type (competitive and non-competitive) CYP1B1 inhibitor [7].

The inhibition of CYP1-related activity by amiloride derivatives did not occur in response to cariporide, $\mathrm{a} \mathrm{Na}^{+}$/ $\mathrm{H}^{+}$exchanger blocker that does not share structural similarities with amiloride derivatives [26], thus indicating that the inhibitory effects of the latter compounds towards CYP1 activity were not explained by an alteration of $\mathrm{Na}^{+} / \mathrm{H}^{+}$ exchanger. This also favors the idea that specific structural elements exhibited by amiloride and its analogues are likely to be required for interaction with CYP1 isoforms. In line with this, it seems plausible that the pyrazinyl group found in amiloride derivatives but also in some distinct CYP1 inhibitors, such as the dithiolethione oltipraz, may be important to consider. The fact that dithiolethiones lacking such a pyrazinyl group failed to interact with CYP1 isoforms fully supports this hypothesis [9]. Interestingly, the two amiloride analogues with a side alkyl chain, i.e. EIPA and MIA, were more active than amiloride for inhibiting EROD activity, suggesting that the presence of such a structural element was also a critical parameter for CYP1 blockage.

CYP1 inhibition by EIPA was not associated with a reduction of BP-mediated up-regulation of CYP1A1 expression, indicating that EIPA lacks arylhydrocarbon receptor antagonist properties. By contrast, several CYP1 inhibitors, such as $\alpha$-naphtoflavone [29], resveratrol [5] or galangin [4], block arylhydrocarbon receptor activation by PAHs and therefore inhibit both activity of CYP1A1 and induction of its expression. Through interacting with the arylhydrocarbon receptor, such compounds may also alter other arylhydocarbon receptor-regulated functions, which may limit the use of such compounds as specific inhibitors of CYP1 enzymes.

Inhibition of CYP1-related EROD activity by EIPA was found to be associated with a marked reduction of CYP1dependent conversion of BP into water-soluble metabolites. EIPA also concomitantly decreased BP-derived DNA adducts formation and BP-induced apoptosis in liver epithelial cells. Such data suggest that amiloride derivatives may counteract toxic effects of carcinogens, such as $\mathrm{BP}$, and therefore may present an interest for chemoprevention studies like other CYP1 inhibitors, such as curcumin [30] or resveratrol [31]. Interestingly, EIPA was found to block the two major CYP1 isoforms involved in bioactivation of PAHs, i.e. CYP1A1 and CYP1B1 [32], likely indicating a major inhibition of PAH bioactivation pathways. In addition, the fact that amiloride and its derivatives have been reported to decrease cell proliferation and to inhibit tumor growth may also contribute to potential chemopreventive properties of these compounds $[11,12]$. Nevertheless, before considering them as chemopreventive agents, effective protective effects of amiloride and derivatives should also be demonstrated in experimental carcinogenesis models. Regarding this point, it is worth noting that administration of amiloride to rats has been shown to significantly reduce the incidence of colon tumors experimentally induced by azoxymethane [33]; it also inhibited gastric carcinogenesis triggered by $N$-methyl- $N^{\prime}$-nitro- $N$-nitrosoguanidine [13]. Interestingly, the inhibition of CYP1 activity by amiloride and its derivatives occurs at concentrations that may be reached in vivo; indeed, amiloride concentrations on airway surfaces after nebulization corresponded to $160 \mu \mathrm{M}$ in humans [34] and EIPA concentrations higher than $1 \mu \mathrm{M}$ have been observed in mouse tissues after intraperitoneal injection [35].

In conclusion, amiloride derivatives, especially EIPA, were identified as constituting a new chemical class of CYP1 inhibitors. Through this action, EIPA was able to prevent toxic effects of procarcinogens, such as BP, requiring CYP1-related bioactivation, suggesting that the use of amiloride derivatives may be interesting to consider for chemoprevention studies.

\section{Acknowledgments}

This work was supported by grants from the Institut National de Recherche et de Sécurite (INRS) and the 
Ministère de l'Aménagement du Territoire et de l'Environnement. We thank Prof. A. Guillouzo and Dr. V. Lecureur for helpful critical reading of the manuscript.

\section{References}

[1] Conney AH. Induction of microsomal enzymes by foreign chemicals and carcinogenesis by polycyclic aromatic hydrocarbons: G.H.A. Clowes Memorial Lecture. Cancer Res 1982;42(12):4875-917.

[2] Melendez-Colon VJ, Luch A, Seidel A, Baird WM. Cancer initiation by polycyclic aromatic hydrocarbons results from formation of stable DNA adducts rather than apurinic sites. Carcinogenesis 1999;20(10): 1885-91.

[3] Whitlock Jr JP. Induction of cytochrome P4501A1. Annu Rev Pharmacol Toxicol 1999;39:103-25.

[4] Ciolino HP, Yeh GC. The flavonoid galangin is an inhibitor of CYP1A1 activity and an agonist/antagonist of the aryl hydrocarbon receptor. Br J Cancer 1999;79(9/10):1340-6.

[5] Ciolino HP, Yeh GC. Inhibition of aryl hydrocarbon-induced cytochrome P-450 1A1 enzyme activity and CYP1A1 expression by resveratrol. Mol Pharmacol 1999;56(4):760-7.

[6] Kleiner HE, Reed MJ, DiGiovanni J. Naturally occurring coumarins inhibit human cytochromes $\mathrm{P} 450$ and block benzo[ $a$ ]pyrene and 7,12dimethylbenz $[a]$ anthracene DNA adduct formation in MCF-7 cells. Chem Res Toxicol 2003;16(3):415-22.

[7] Takahashi E, Fujita K, Kamataki T, Arimoto-Kobayashi S, Okamoto $\mathrm{K}$, Negishi T. Inhibition of human cytochrome P450 1B1, 1A1 and $1 \mathrm{~A} 2$ by antigenotoxic compounds purpurin and alizarin. Mutat Res 2002;508(1/2):147-56.

[8] Doostdar H, Burke MD, Mayer RT. Bioflavonoids: selective substrates and inhibitors for cytochrome P450 CYP1A and CYP1B1. Toxicology 2000;144(1-3):31-8.

[9] Langouet S, Furge LL, Kerriguy N, Nakamura K, Guillouzo A, Guengerich FP. Inhibition of human cytochrome P450 enzymes by 1,2-dithiole-3-thione, oltipraz and its derivatives, and sulforaphane. Chem Res Toxicol 2000;13(4):245-52.

[10] Grinstein S, Rotin D, Mason MJ. $\mathrm{Na}^{+} / \mathrm{H}^{+}$exchange and growth factorinduced cytosolic $\mathrm{pH}$ changes. Role in cellular proliferation. Biochim Biophys Acta 1989;988(1):73-97.

[11] Sparks RL, Pool TB, Smith NK, Cameron IL. Effects of amiloride on tumor growth and intracellular element content of tumor cells in vivo. Cancer Res 1983;43(1):73-7.

[12] Horvat B, Taheri S, Salihagic A. Tumour cell proliferation is abolished by inhibitors of $\mathrm{Na}^{+} / \mathrm{H}^{+}$and $\mathrm{HCO}_{3}{ }^{-} / \mathrm{Cl}^{-}$exchange. Eur $\mathrm{J}$ Cancer 1992;29A(1):132-7.

[13] Tatsuta M, Iishi H, Baba M, Uehara H, Nakaizumi A, Taniguchi H. Inhibition by amiloride of gastric carcinogenesis induced by $\mathrm{N}$ methyl- $N N^{\prime}$-nitro- $N$-nitrosoguanidine in Wistar rats. $\mathrm{Br} \mathrm{J}$ Cancer 1993;67(5):1011-4.

[14] Guguen-Guillouzo C, Campion JP, Brissot P, Glaise D, Launois B, Bourel M, et al. High yield preparation of isolated human adult hepatocytes by enzymatic perfusion of the liver. Cell Biol Int Rep 1982;6(6):625-8.

[15] Payen L, Courtois A, Langouet S, Guillouzo A, Fardel O. Unaltered expression of multidrug resistance transporters in polycyclic aromatic hydrocarbon-resistant rat liver cells. Toxicology 2001;156(2/3):109-17.

[16] Chirgwin JM, Przybyla AE, MacDonald RJ, Rutter WJ. Isolation of biologically active ribonucleic acid from sources enriched in ribonuclease. Biochemistry 1979;18(24):5294-9.

[17] Raymondjean M, Kneip B, Schapira G. Preparation and characterization of mRNAs from rat heart muscle. Biochimie 1983;65(1):65-70.
[18] Affolter M, Labbe D, Jean A, Raymond M, Noel D, Labelle Y, et al. cDNA clones for liver cytochrome P-450s from individual aroclortreated rats: constitutive expression of a new P-450 gene related to phenobarbital-inducible forms. DNA 1986;5(3):209-18.

[19] Le Ferrec E, Lagadic-Gossmann D, Rauch C, Bardiau C, Maheo K, Massiere F, et al. Transcriptional induction of CYP1A1 by oltipraz in human Caco-2 cells is aryl hydrocarbon receptor- and calcium-dependent. J Biol Chem 2002;277(27):24780-7.

[20] Bradford MM. A rapid and sensitive method for the quantitation of microgram quantities of protein utilizing the principle of protein-dye binding. Anal Biochem 1976;72:248-54.

[21] Burke MD, Thompson S, Elcombe CR, Halpert J, Haaparanta T, Mayer RT. Ethoxy-, pentoxy- and benzyloxyphenoxazones and homologues: a series of substrates to distinguish between different induced cytochromes P-450. Biochem Pharmacol 1985;34(18):3337-45.

[22] Vernhet L, Allain N, Le Vee M, Morel F, Guillouzo A, Fardel O. Blockage of multidrug resistance-associated proteins potentiates the inhibitory effects of arsenic trioxide on CYP1A1 induction by polycyclic aromatic hydrocarbons. J Pharmacol Exp Ther 2003;304(1): 145-55.

[23] Piver B, Berthou F, Dreano Y, Lucas D. Differential inhibition of human cytochrome $\mathrm{P} 450$ enzymes by $\varepsilon$-viniferin, the dimer of resveratrol: comparison with resveratrol and polyphenols form alcoholized beverages. Life Sci 2003;73:1199-213.

[24] Landers JP, Bunce NJ. The Ah receptor and the mechanism of dioxin toxicity. Biochem J 1991;276(Pt 2):273-87.

[25] Huberman E, Selkirk JK, Heidelberger C. Metabolism of polycyclic aromatic hydrocarbons in cell cultuires. Cancer Res 1971;31(12): 2161-7.

[26] Putney LK, Denker SP, Barber DL. The changing face of the $\mathrm{Na}^{+} / \mathrm{H}^{+}$ exchanger, NHE1: structure, regulation, and cellular actions. Annu Rev Pharmacol Toxicol 2002;42:527-52.

[27] Sparfel L, Loewert M, Huc L, Payen L, Guillouzo A, LagadicGossmann D, et al. Acute cytotoxicity of the chemical carcinogen 2-acetylaminofluorene in cultured rat liver epithelial cells. Toxicol Lett 2002;129(3):245-54.

[28] Werlinder V, Backlund M, Zhukov A, Ingelman-Sundberg M. Transcriptional and post-translational regulation of CYP1A1 by primaquine. J Pharmacol Exp Ther 2001;297(1):206-14.

[29] Blank JA, Tucker AN, Sweatlock J, Gasiewicz TA, Luster MI. Alphanaphthoflavone antagonism of 2,3,7,8-tetrachlorodibenzo-p-dioxininduced murine lymphocyte ethoxyresorufin- $O$-deethylase activity and immunosuppression. Mol Pharmacol 1987;32(1):169-72.

[30] Deshpande SS, Ingle AD, Maru GB. Chemopreventive efficacy of curcumin-free aqueous turmeric extract in 7,12-dimethylbenz $[a]$ anthracene-induced rat mammary tumorigenesis. Cancer Lett 1998; 123(1):35-40.

[31] Jang M, Cai L, Udeani GO, Slowing KV, Thomas CF, Beecher CW, et al. Cancer chemopreventive activity of resveratrol, a natural product derived from grapes. Science 1997;275(5297):218-20.

[32] Shimada T, Hayes CL, Yamazaki H, Amin S, Hecht SS, Guengerich FP, et al. Activation of chemically diverse procarcinogens by human cytochrome P-450 1B1. Cancer Res 1996;56(13):2979-84.

[33] Tatsuta M, Iishi H, Baba M, Uehara H, Nakaizumi A. Chemoprevention by amiloride of experimental carcinogenesis in rat colon induced by azoxymethane. Carcinogenesis 1995;16(4):941-2.

[34] Noone PG, Regnis JA, Liu X, Brouwer KL, Robinson M, Edwards L, et al. Airway deposition and clearance and systemic pharmacokinetics of amiloride following aerosolization with an ultrasonic nebulizer to normal airways. Chest 1997;112(5):1283-90.

[35] Lee C, Tannock I. Pharmacokinetic studies of amiloride and its analogs using reversed-phase high-performance liquid chromatography. J Chromatogr B Biomed Appl 1996;685(1):151-7. 